\title{
The analysis of education principle implementation in an online counseling approach: a preliminary study based on analysis from a Rasch modeling perspective
}

\author{
Zadrian $\operatorname{Ardi}^{1^{*}}$ \\ ${ }^{1}$ Universitas Negeri Padang \\ ${ }^{*}$ Corresponding author, ఏ" e-mail: zadrian@fip.unp.ac.id
}

\begin{abstract}
Education as part of universal human activities can occur in any form and situation, where it is seen through the learning process. The counseling process which is an integral part of education also undergoes a transformation of service processes and methods. However, the research about the application of the education principles in the long-distance counseling process has not been available well until now. This research aims to study the implementation of the principles of education in the online counseling process through a rasch modeling perspective. The sample in this study amounted to 174 people spread across Indonesia with various types of demographics. The results of the study show that the application of the principle of education in online counseling services can significantly suppress the problematic condition of the respondent. In addition, in certain cases, online counseling services are carried out as a quick or first aid to the problematic conditions experienced by the client. The implementation that will be discussed from this approach relates to development of self potential, self-control, personality development, independence development, development of intelligence and skills
\end{abstract}

Keywords: Education principle, online counseling, Rasch model

How to Cite: Ardi, Z. (2019). An analysis of education principle implementation in an online counseling approach: a preliminary study based on analysis using the Rasch model. COUNS-EDU: The International Journal of Counseling and Education, 4(2): pp. 59-68. DOI: https://doi.org/10.23916/0020190418720

This is an open access article distributed under the Creative Commons Attribution License, which permits unrestricted use distribution, and reproduction in any medium, provided the original work is properly cited. (C2019 by author.

\section{Introduction}

The individuals that have mental hygiene are individuals who lead effective lives with structured positive behavior patterns (Hanum, Prayitno, \& Nirwana, 2015; Jayanti, Romlah, \& Saregar, 2016; Sudarsana, 2017). These individuals have a developing life, both from intellectual abilities, independence, having self-control, religious-spiritual abilities, and various skills that are useful for themselves, society and the country (Arafani, Ilyas, \& Zikra, 2018; Hashim, 2018; Wijaya \& Tori, 2018). This is reflected in the principles of implementing education in Indonesia. However, various conditions from within and outside the individual could hinder such self-development, thus creating an effective daily life condition disrupted.

Psychologically healthy living conditions are important conditions that are often missed by individual and professional attention (Ancker et al., 2015; Owens et al., 2017; Scheid \& Wright, 2017; Segal, Qualls, \& Smyer, 2018). Exposure to data from the World Health Organization (WHO) suggests that mental health condition of Indonesian adolescents shows that $5 \%$ of the population experiences anxiety, $7 \%$ experiences feelings of loneliness, and there are more than $20 \%$ teenagers become victims of bullying (World Health Organization, 2017). This happens because of the high gap between the 
availability of professional staff who can provide counseling services to help clients with the number of individuals experiencing problems. Another issue that is the cause of the lack of optimal counseling services in Indonesia is the low information obtained by individuals regarding acceptable services related to the problem.

To overcome these conditions and the implementation of the principles of education through counseling services, it is necessary to develop an approach, method and media that supports the existence of remote (distance) counseling services, namely online counseling services (Jones, 2018; Mishna, Fantus, \& McInroy, 2017; Otten, Birnie, Ranchor, \& van Langen, 2016; Stommel \& Te Molder, 2015). Online counseling services are the services that provided by professionals (counselors) to clients that aims to deal with disturbed daily conditions of effective life, the development of independence and self-control through the formation of positive behaviors structured in the frame of education principles with internet media and platforms that support them. (Ardi, Putra, \& Ifdil, 2017; Ardi, Viola, \& Sukmawati, 2018; Ardi \& Yendi, 2013; Ifdil \& Ardi, 2013). The implementation of online counseling services at the beginning of its development was carried out through web and system assistance that enabled the interaction of counselors and clients, but in its development there have been developed more interactive and real-time platforms, for example through the development of online counseling service applications with the Android platform (Cipolletta \& Mocellin, 2018; Cipolletta, Votadoro, \& Faccio, 2017; Marchiori \& Cantoni, 2018; Sweet et al., 2017).

The basic of the online counseling approach development is based on the potential of internet media which has proven to have experienced a very significant increase in the last few decades. In terms of internet usage alone, currently in Indonesia, there is an increase of 500\% in 2015 compared to year, 2000. It is known that more than 50\% of Indonesia's population (120 million residents) are active internet users (Arjadi, Nauta, \& Bockting, 2018). In the latest developments, the use of Smartphone as one of the most recent internet platforms constitutes $95 \%$ of the total internet users (Asosiasi Penyedia Jasa Internet Indonesia, 2015).

This great potential can be used as a counseling services with long distance formats (Ardi et al., 2018). The implementation of remote counseling through internet media will open up opportunities for various clients who cannot meet the counselor in a short time (Ardi et al., 2019; Daharnis et al., 2018; Fitria et al., 2018) (in the sense that the problems experienced are an important problem to immediately consult with the counselor) (Amichai-Hamburger, Klomek, Friedman, Zuckerman, \& Shani-Sherman, 2014; Kofinas et al., 2014; Wong, Bonn, Tam, \& Wong, 2018), clients who experience various obstacles in meeting counselors, reluctant clients meeting the counselor in the first session, as well as the conditions of other clients who need immediate treatment (Ballesteros \& Hilliard, 2016; Hintz, Frazier, \& Meredith, 2015; Pordelan, Sadeghi, Abedi, \& Kaedi, 2018; Sampson \& Makela, 2014). In another point of view, the existence of online counseling will open the opportunity to expand information about various aspects that can be handled by the counselor, where these aspects have not been known or unknown by the wider community in Indonesia. With these conditions, phenomena, and assumptions, various possibilities for online counseling services can be analyzed, which first conduct an acceptability service analysis and then examine various forms of implementation of the principle of education in online counseling services. This was done with the aim of strengthening online counseling hegemony and reviewing the legality, empirical basis, and theoretical online counseling services in the future.

\section{Method}

\section{Participant}

In this research, the respondents that involved were 174 people with diverse demographic variants. This study involved respondents consisting of $25.85 \%$ men and $74.15 \%$ women, $31.79 \%$ working, and the remaining $68.21 \%$ are respondents who have not worked.

\section{Measuring}

This study uses the Acceptability of Mental-Health Mobile App Survey (AMMS) with Cronbach Alpha-KR20 value of 0.89 . This inventory measures the level of acceptance of respondents to counseling services by using a remote/distance format based on the internet and measuring several aspects that related to the acquisition of respondents in the service. In addition, the validity condition of the measuring instrument is also known through the uni-dimensionality inventory value that produces raw variance 
explained by measure conditions of $50.7 \%$ and the total unexplained variable in $11.1 \%$, so that this meets instrument validation requirements, which is this instrument can explain the measured conditions well.

\section{Data Analysis}

The findings and field data were analyzed using Rasch analysis. This test was aimed to obtaining robust and accurate data on the outcomes and conditions of the respondents. Testing using Rasch analysis is done through Winstep software version 4.01 and datasets from research can be accessed in the Open Science Framework. In addition to the analysis using the Rasch model, testing was also conducted with an analysis of network psychometric through JASP software. This test is done to see the relationship conditions and the contribution between items in real-time and accurately through networks.

\section{Results and Discussions}

The measurement is done to see the condition of uni-dimensionality of the item and see the sense of bias of the item through a series of tests through Knox Cube Test (KCT) in Figure 1. Based on the conditions of the KCT, it is known that in general the bias condition is not seen comprehensively, but there are some respondents who are thrown away from the mean line. This condition can be seen from the dash line that shows the trend-line of research data. The black curved shows an estimate of $95 \%$ of the trust value and significance of the data collected, this is obtained because each point has its own confidence interval. The interpretation of this condition shows that there are some respondents who experience gender bias ( $\mathrm{Y}$-axis and $\mathrm{X}$-axis). There was one respondent from a female who was biased towards the response item, and three respondents from the male who experienced a bias response. With the condition that at least there is a bias in the respondents, it can be concluded that the acquisition of respondents' acceptability conditions for online counseling services is more reliable. This will affect the analysis process and the level of acceptance of the research conclusions. In the condition of the data in Figure 1, it can be concluded that the level of acceptance of the measurement results (logit measure) on items for each respondent is acceptable. This is based on the condition that respondents who experience bias are not classified as numerous and include error measurement that can be tolerated (the boundary conditions will also be supported by the Outfit measure data in Table 1.

The next analysis that needs to be done on the acceptance of respondents to take part in online counseling sessions is in terms of the characteristics of the items answered by respondents and then seen the empirical score conditions, compared to the expected item response model and the Test of Information Function (TIF) carried out in one test. The test results are presented in Figure 2.

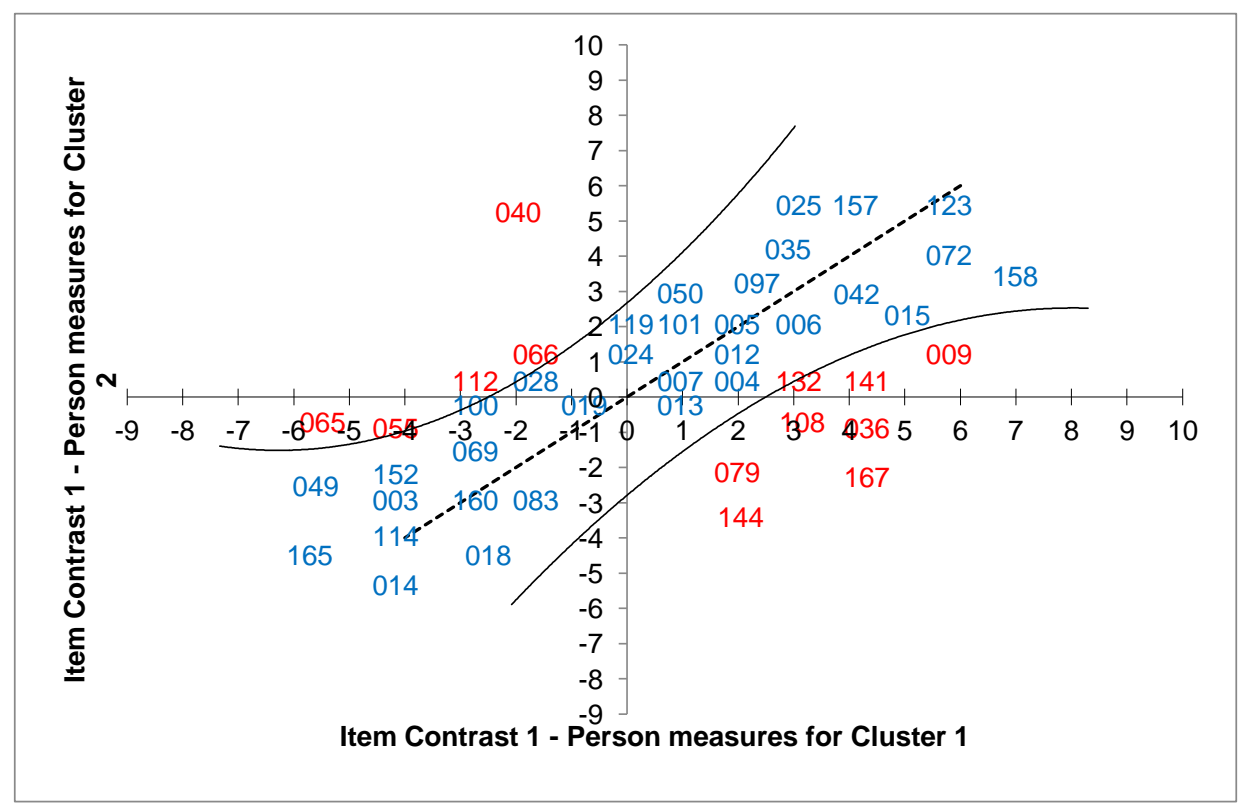

Figure 1 Item Contrast 1 - Person measures for Clusters 1 and 2 
There are several items with extreme answers when compared to other items. This condition becomes an important reference in analyzing the items and conditions of the respondents so that in the end they will be able to see how their implementation in counseling practices is part of the education process.

\section{Item Characteristic Curves}

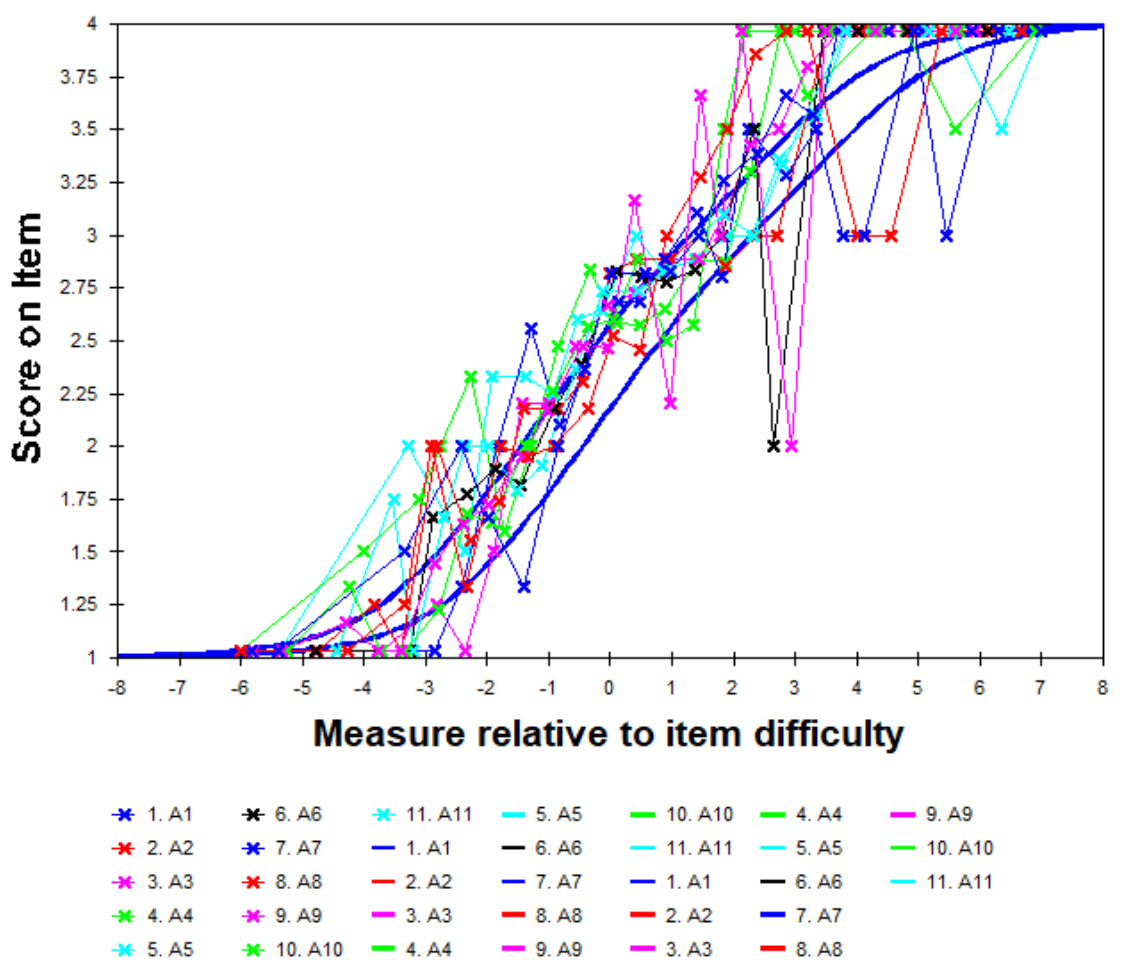

Figure 2 Item Characteristic Curves based on Score Item and measure relative to item difficulty

The achievement conditions in Figure 2 show that items A6 and A9 are two items with extreme characteristic conditions when compared to the model curve and the TIF curve. The achievement of items through item characteristic charts will affect the condition of item categorization through variable map items (wrights map). This map will display the level of acceptability of the respondent's conditions for online counseling services.

As explained in Figure 3, it is known that there are respondents who have a high, moderate and low acceptability level in online counseling services. The finding that all items are in a moderate condition can be interpreted that items can clearly divide clearly which respondents are close to the mean logit and which ones are at high and low levels clearly and robustly. This is a strong basis for grouping respondents on the based on question items. On the other hand, the high level of respondents' acceptance of online counseling services can be interpreted that this service with remote formats can be one of the accurate media to help clients solve their problems. With the high interest of respondents in accepting the format of online counseling services, this will have an impact on the substance of the provision of counseling services as an integral part of education. In other words, the implementation of the educational process which is currently experiencing dynamics along with technological changes and unlimited distance and time, counseling services can also carry out the same process.

The next condition that can encourage the occurrence of online counseling services in implementing education is to conduct psychometrics network analysis of the conditions of acceptability of online counseling services, the results of the analysis in Figure 4. 


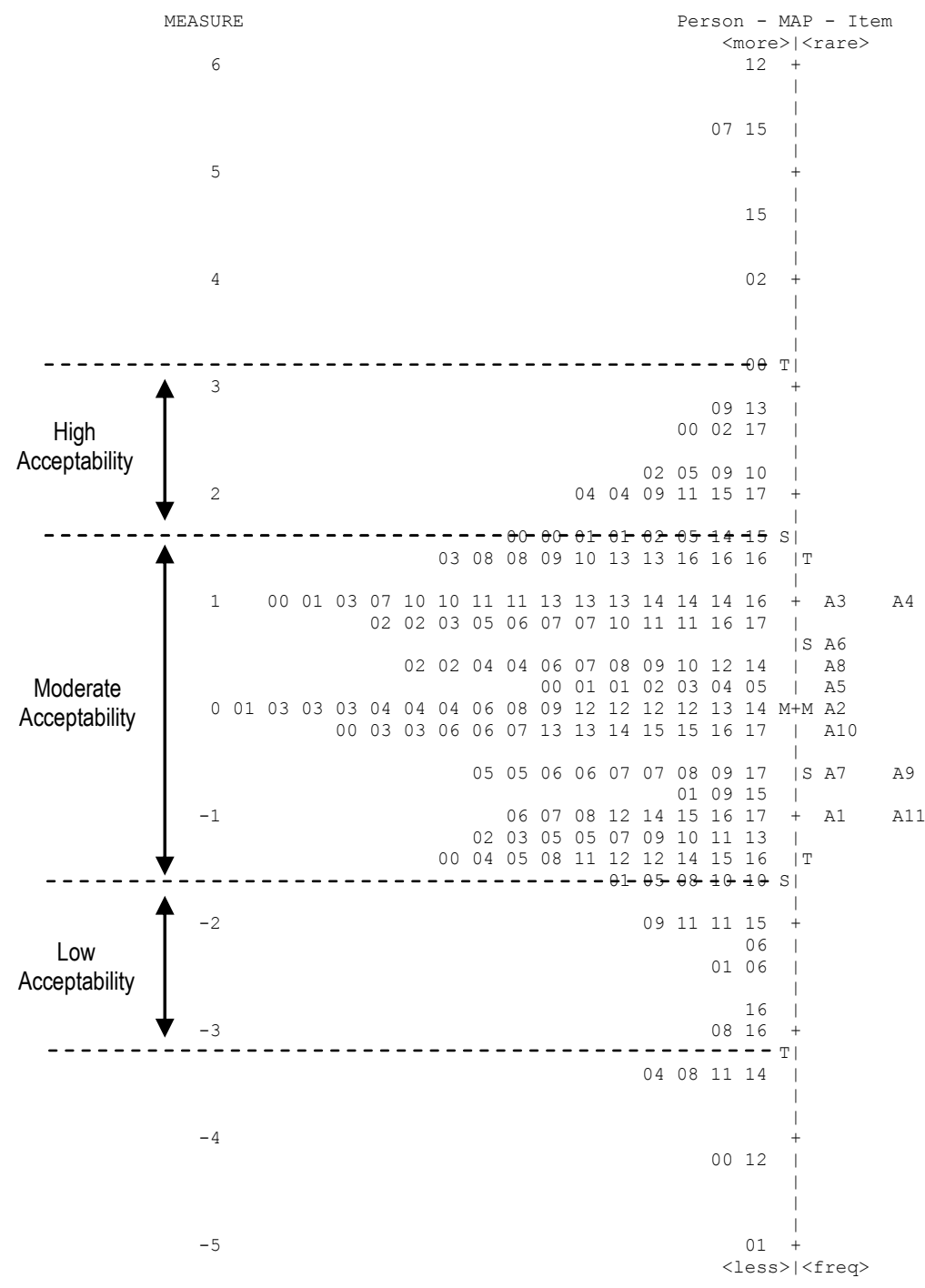

Figure 3 Wright Map of Online Counseling Acceptability

Psychometric network analysis shows that there are some related items and indicators of online counseling services and their relation to the respondent's behavior towards the service. Through this analysis, we can see a strong correlation with the green line as a correlation with a positive direction, and a red line that indicates the opposite condition. In Figure 4, it can be seen that some conditions that have a strong correlation are in items $\mathrm{A} 2$ and $\mathrm{A} 7$, where this condition means that the respondent has a strong desire to find important information about his mental health condition, where the conditions and solutions regarding the disruption of his life want they found through online counseling services and Smartphone applications.

When viewed based on the acquisition conditions of logit values on items that have a strong correlation with each other, it is known that in general the respondent's logit value for online counseling services and the availability of mental health information through applications are classified as high and tend to be above the mean. This indicates directly that online counseling services are one of the alternative service formats that have great potential, especially in the face of the segmentation of generations who are currently accustomed to using internet technology. The study of the implementation of the format of online counseling services in the study of its implementation of education will be discussed further in the section discussion. 


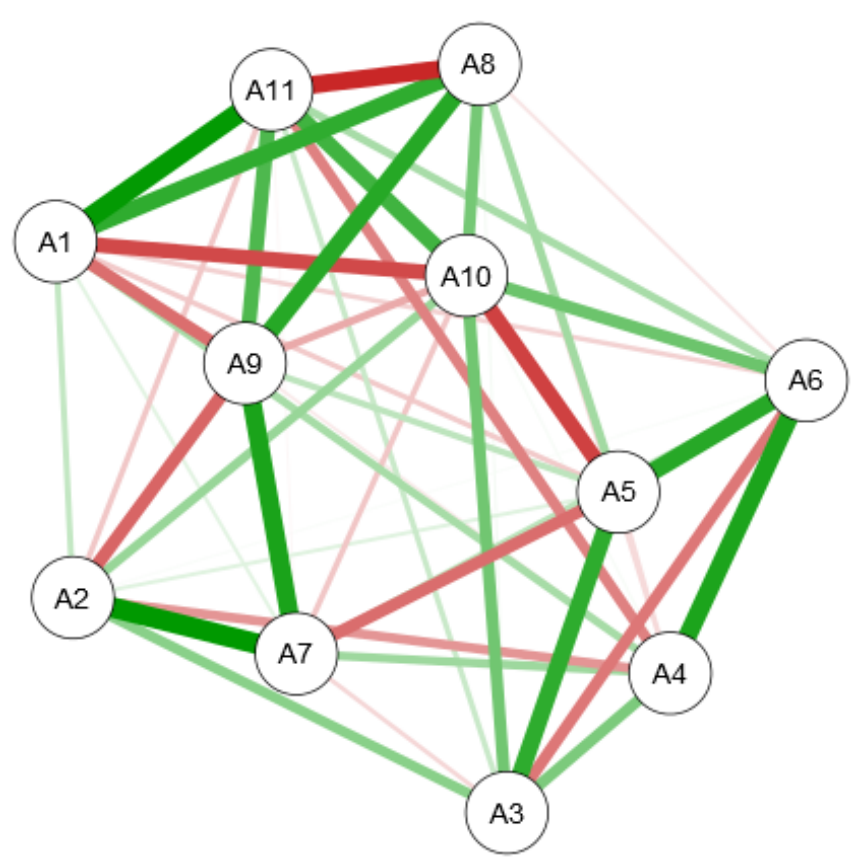

Figure 4 The acceptability network model of respondents who had received mental health intervention by internet

The study of the education principle implementation through counseling services began with a study of the conditions of acceptability of the online counseling service. This is based on the condition of the respondents' high acceptance of online counseling services, so that the level of acceptance will facilitate the process of implementing the education process itself.

In accordance with the study presented in the introduction, the implementation of the value of education in counseling services is in accordance with the educational foundation of the national education system. The application of the educational principle cannot be separated from the grid or blueprint revealed by inventory. The analysis and study related to the application of the principles of education are outlined as follows:

\section{Development of self potential}

As an integral part of education, counseling services aim to develop the client's self-potential when the service takes place in a condition that is disrupted or in a condition to be optimally developed (Ardi, 2017; Ardi \& Maizura, 2018). The results showed that respondents' desire to seek counseling services through online (long distance) format was in the high category, this was evidenced by the acquisition of logit for the condition of respondents wanting to obtain information about self-development and mental health through online counseling applications of -0.51 (logistic rescaling value 44.91, with MNSQ 0.75 Outfit). This proves that with the existence of remote formats, the process of developing self potential can still be done, which in this case is proven by the high interest of respondents to gain knowledge and information about their potential.

\section{Self-control}

Self-control is the ability to guide behavior and suppress impulses that arise from within that can result in maladaptive behavior (Ardi \& Erlamsyah, 2017; Ardi \& Sukmawati, 2017; Daharnis, Ardi, \& Ifdil, 2018). In another definition, self-control is a regulation of a person's physical, psychological and behavioral processes. The counseling process basically addresses and intervenes in the development of selfcontrol abilities. Based on the research findings, it is known that respondents prefer to contact counselors through an online counseling application to raise the issue, this can mean that instead of channeling disrupted daily effective conditions through other media (such as social media), respondents prefer to seek online counselors. 


\section{Personality development}

One of the most crucial aspects in the counseling process is the development of the client's personality. This also happens in the process of online counseling services (Chung, 2014; Galassi, 2017). The client's need for positive personality development is evidenced by the achievement in terms of the desire that the psychological condition is always monitored by the counselor through online counseling with a logit value of $0.53,52.9$ rescaling logit and MNSQ Outfit of 0.87 , meaning that the implementation of the principle of education in developing personality respondents through online counseling services are very possible. Various approaches to counseling can be done through the use of the internet-based remote format. An empirically proven approach can help clients in developing personalities and alleviating problems through online media such as the Cognitive Behavior Therapy (CBT) approach, Rational Emotive Behavior Therapy (REBT) and Solution Focused Brief Counseling (SFBC). These various approaches, especially SFBC, are approaches that are in line with the characteristics of long-distance counseling services, given the objectives and objectives of the approach and the value of match interventions with the media counseling used (Franklin, Zhang, Froerer, \& Johnson, 2017; Kramer, Conijn, Oijevaar, \& Riper, 2014; Pichot \& Coulter, 2014).

\section{Independence Development}

One of the objectives of national education is independent individuals. The development of independence is in the area of counseling services, both from individual counseling services as well as classical formations. With these various formats, the development of independence can also be done through online counseling services. So that the development of independence with characteristics; (1) understand and accept themselves positively and dynamically, (2) understand and accept the environment objectively and dynamically, (3) make appropriate decisions, (4) direct themselves according to the decision, (5) realize themselves optimally, can be done effectively (Hanum et al., 2015; Marjohan, 2012; Prayitno, 2009; Prayitno \& Amti, 2004). The conditions of independence that are realized through online counseling services can be carried out efficiently, this is supported by the enthusiasm of the respondents to get services through the remote format. Of course the service is supported by a variety of effective approaches used through this format.

\section{Development of intelligence and skills}

Intelligence and skills are two aspects that support each other in individual self-development (Ardi \& Sisin, 2018; Daharnis et al., 2018). The educational process in essence leads to the condition that individuals can survive in various conditions that require the use of intelligence and skills. One of the real efforts in developing intelligence and skills is by providing counseling services. Through an online counseling service approach, the development of intelligence and client skills will be optimized through various advantages of online counseling services, such as ease of information and the speed of response of counselors in responding to client problems. But the thing that needs to be considered in this approach is that not all types of client problem conditions can be intervened through remote formats. In some conditions, online counseling services are as initial aid or first aid for problematic conditions in clients.

\section{Conclusions}

Online counseling services basically also carry out the principle of education, in accordance with the basis of counseling services in conventional / face-to-face counseling. The difference between online counseling and conventional approaches is on service delivery media, service settings, service formats and approaches taken. In this regard, online counseling services use an effective approach to this type of problem with short and powerful interventions. Some of these approaches include the approach to Solution Focused Brief Counseling (CBT), Cognitive Behavior Therapy (CBT) and Rational Emotive Behavior Therapy (REBT), in which various approaches have been examined for use through a series of previous researches. Further on the implementation of the principle of education in online counseling services is also related to the conditions of acceptability of online counseling services. The application of the principle of education will only occur with the acceptance of the service by the client. The condition of clients who are more comfortable interacting with counselors and the need to obtain services from counselors through online media opens up a great opportunity in the process of implementing the online counseling service. By analyzing the conditions of acceptability, it can be concluded that the implementation of education in online counseling services can be effectively and efficiently carried out. 
However, in some aspects and cases of clients, not all problems can be resolved thoroughly through online counseling sessions. In this case, it still requires further sessions in face-to-face format.

\section{References}

Amichai-Hamburger, Y., Klomek, A. B., Friedman, D., Zuckerman, O., \& Shani-Sherman, T. (2014). The future of online therapy. Computers in Human Behavior, 41, 288-294.

Ancker, J. S., Witteman, H. O., Hafeez, B., Provencher, T., Van de Graaf, M., \& Wei, E. (2015). The invisible work of personal health information management among people with multiple chronic conditions: qualitative interview study among patients and providers. Journal of Medical Internet Research, 17(6).

Arafani, A., Ilyas, A., \& Zikra, Zi. (2018). Learning Management of UNP's Students and its Implication to Guidance and Counseling. International Journal of Research in Counseling and Education, 1(3), 1-7. https://doi.org/10.24036/0022za0002

Ardi, Z., Rangka, I. B., Ifdil, I., Suranata, K., Azhar, Z., Daharnis, D., ... Alizamar, A. (2019). Exploring the elementary students learning difficulties risks on mathematics based on students mathematic anxiety, mathematics self-efficacy and value beliefs using rasch measurement. In Journal of Physics: Conference Series (Vol. 1157, p. 32095). IOP Publishing.

Ardi, Z., Sukmawati, I., Ifdil, I., Afdal, A., Rangka, I. B., \& Suranata, K. (2018). Exploring the acceptability of internet-based mental health mobile app services using network psychometrics analysis. In Journal of Physics: Conference Series (Vol. 1114, p. 12106). IOP Publishing.

Ardi, Z. (2017). Unsuitable Majoring: Does the Reorientation Would Help the Student for Revitalize Learning Activities? In Proceedings of the 9th International Conference for Science Educators and Teachers (ICSET 2017). Paris, France: Atlantis Press. https://doi.org/10.2991/icset-17.2017.69

Ardi, Z., \& Erlamsyah, E. (2017). Peningkatan Kualitas Penulisan Artikel Ilmiah bagi Kepala Sekolah. Jurnal Aplikasi IPTEK Indonesia, 1(1), 25-34.

Ardi, Z., \& Maizura, N. (2018). The Psychological Analysis of Divorce at Early Marriage. International Journal of Research in Counseling and Education, 1(3), 27-32.

Ardi, Z., Putra, M. R. M., \& Ifdil, I. (2017). Ethics And Legal Issues In Online Counseling Services: Counseling Principles Analysis. Jurnal Psikologi Pendidikan Dan Konseling: Jurnal Kajian Psikologi Pendidikan Dan Bimbingan Konseling, 15-22.

Ardi, Z., \& Sisin, M. (2018). The Contribution of Assertive Technique Behavioral Counseling to Minimize the Juvenile Delinquency Behavior. Jurnal Konseling Dan Pendidikan, 6(2), 67-77.

Ardi, Z., \& Sukmawati, I. (2017). Social Media and the Quality of Subjective Well-Being; Counseling Perspective in Digital Era. Open Science Framework. October.

Ardi, Z., Viola, K., \& Sukmawati, I. (2018). An Analysis of Internet Abuses Impact on Children's Moral Development. JPPI (Jurnal Penelitian Pendidikan Indonesia), 4(1), 44-50. Retrieved from http://jurnal.iicet.org/index.php/jppi/article/view/192

Ardi, Z., \& Yendi, F. M. (2013). Konseling Online: Sebuah Pendekatan Teknologi Dalam Pelayanan Konseling. Jurnal Konseling Dan Pendidikan, 1(1), 1-5.

Arjadi, R., Nauta, M. H., \& Bockting, C. L. H. (2018). Acceptability of internet-based interventions for depression in Indonesia. Internet Interventions, 13(April), 8-15. https://doi.org/10.1016/j.invent.2018.04.004

Asosiasi Penyedia Jasa Internet Indonesia. (2015). Profil pengguna internet indonesia. Jakarta: Asosiasi Penyedia Jasa Internet Indonesia.

Ballesteros, J. L., \& Hilliard, R. C. (2016). US-Based Latina/O College Students' Attitudes toward Online Counseling. International Journal for the Advancement of Counselling, 38(4), 269-285.

Chung, J. E. (2014). Social networking in online support groups for health: how online social networking benefits patients. Journal of Health Communication, 19(6), 639-659.

Cipolletta, S., \& Mocellin, D. (2018). Online counseling: An exploratory survey of Italian psychologists' attitudes towards new ways of interaction. Psychotherapy Research, 28(6), 909-924.

Cipolletta, S., Votadoro, R., \& Faccio, E. (2017). Online support for transgender people: an analysis of forums and social networks. Health \& Social Care in the Community, 25(5), 1542-1551.

Daharnis, D., Ardi, Z., Alizamar, A., Ifdil, I., Rangka, I. B., \& Suranata, K. (2018). Adaptation and validation of mathematics anxiety: Rasch and network psychometrics analysis. In Journal of Physics: Conference Series (Vol. 1114, p. 12113). IOP Publishing. 
Daharnis, D., Ardi, Z., \& Ifdil, I. (2018). The Improved of Counselor Competencies through Scientific Article Writing Training Using Digital Citation Application. Jurnal Konseling Dan Pendidikan, 6(1), 8.

Fitria, L., Ifdil, I., Erwinda, L., Ardi, Z., Afdal, A., Sari, A. P., ... Churnia, E. (2018). Exploring internet addiction on adolescents. In 2018 Workshop on Multidisciplinary and Its Applications: Applied Mathematics, Computer Science, Information Systems, and Information Technology, WMA-Mathcomtech 2018 (Vol. 1114). Universitas Putra Indonesia YPTK, Padang, Indonesia: Institute of Physics Publishing. https://doi.org/10.1088/1742-6596/1114/1/012076

Franklin, C., Zhang, A., Froerer, A., \& Johnson, S. (2017). Solution Focused Brief Therapy: A Systematic Review and Meta- Summary of Process Research. Journal of Marital and Family Therapy, 43(1), 1630.

Galassi, J. (2017). Strengths-based school counseling: Promoting student development and achievement. Routledge.

Hanum, M., Prayitno, P., \& Nirwana, H. (2015). Efektifitas Layanan KonselingPerorangan Meningkatkan Kemandirian Siswa Dalam Menyelesaikan Masalah Belajar. Konselor, 4(3), 162168.

Hashim, H. (2018). Application of technology in the digital era education. International Journal of Research in Counseling and Education, 1(2), 1-5. https://doi.org/10.24036/002za0002

Hintz, S., Frazier, P. A., \& Meredith, L. (2015). Evaluating an online stress management intervention for college students. Journal of Counseling Psychology, 62(2), 137.

Ifdil, I., \& Ardi, Z. (2013). Konseling Online Sebagai Salah Satu Bentuk Pelayanan E-konseling. Jurnal Konseling Dan Pendidikan, 1(1), 15-22. Retrieved from http://jurnal.konselingindonesia.com/index.php/jkp/article/viewFile/4/193

Jayanti, R. D., Romlah, R., \& Saregar, A. (2016). Efektivitas Pembelajaran Fisika Model Problem Based Learning (PBL) melalui Metode POE terhadap Kemampuan Berpikir Tingkat Tinggi Peserta Didik. In Seminar Nasional Pendidikan (pp. 208-214).

Jones, J. (2018). Combining the Creative Therapies with Technology: Using Social Media and Online Counseling to Treat Clients. Taylor \& Francis.

Kofinas, J. D., Varrey, A., Sapra, K. J., Kanj, R. V, Chervenak, F. A., \& Asfaw, T. (2014). Adjunctive social media for more effective contraceptive counseling: a randomized controlled trial. Obstetrics \& Gynecology, 123(4), 763-770.

Kramer, J., Conijn, B., Oijevaar, P., \& Riper, H. (2014). Effectiveness of a web-based solution-focused brief chat treatment for depressed adolescents and young adults: randomized controlled trial. Journal of Medical Internet Research, 16(5).

Marchiori, E., \& Cantoni, L. (2018). Applying the counseling-learning approach to a tourism-related massive open online course. Journal of Teaching in Travel \& Tourism, 18(1), 58-74.

Marjohan. (2012). Biografi Keilmuan Prayitno dalam Ranah Konseling dan Pendidikan. Padang: UNP Press.

Mishna, F., Fantus, S., \& McInroy, L. B. (2017). Informal use of information and communication technology: Adjunct to traditional face-to-face social work practice. Clinical Social Work Journal, 45(1), 49-55.

Otten, E., Birnie, E., Ranchor, A. V, \& van Langen, I. M. (2016). Online genetic counseling from the providers' perspective: counselors' evaluations and a time and cost analysis. European Journal of Human Genetics, 24(9), 1255.

Owens, J., Entwistle, V. A., Cribb, A., Skea, Z. C., Christmas, S., Morgan, H., \& Watt, I. S. (2017). "Was that a success or not a success?": a qualitative study of health professionals' perspectives on support for people with long-term conditions. BMC Family Practice, 18(1), 39.

Pichot, T., \& Coulter, M. (2014). Solution-focused brief therapy: Its effective use in agency settings. Routledge.

Pordelan, N., Sadeghi, A., Abedi, M. R., \& Kaedi, M. (2018). How online career counseling changes career development: A life design paradigm. Education and Information Technologies, 1-18.

Prayitno. (2009). Wawasan Profesional Konseling. Padang: UNP Padang.

Prayitno, \& Amti, E. (2004). Dasar-dasar Bimbingan dan Konseling. Jakarta: Rineka Cipta.

Sampson, J. P., \& Makela, J. P. (2014). Ethical issues associated with information and communication technology in counseling and guidance. International Journal for Educational and Vocational Guidance, 14(1), 135-148.

Scheid, T. L., \& Wright, E. R. (2017). A handbook for the study of mental health. Cambridge University Press. Segal, D. L., Qualls, S. H., \& Smyer, M. A. (2018). Aging and mental health. John Wiley \& Sons. 
Stommel, W., \& Te Molder, H. (2015). Counseling online and over the phone: When preclosing questions fail as a closing device. Research on Language and Social Interaction, 48(3), 281-300.

Sudarsana, I. K. (2017). Optimalisasi Pemahaman Ajaran Tri Hita Karana Dalam Meningkatkan Karakter Siswa Sekolah Dasar (Perspektif Psikologi Pendidikan). Prosiding Senada 2, 250-256.

Sweet, K., Hovick, S., Sturm, A. C., Schmidlen, T., Gordon, E., Bernhardt, B., ... Scheinfeldt, L. (2017). Counselees' perspectives of genomic counseling following online receipt of multiple actionable complex disease and pharmacogenomic results: A qualitative research study. Journal of Genetic Counseling, 26(4), 738-751.

Wijaya, H. E., \& Tori, A. R. (2018). Exploring the role of self-control on student procrastination. International Journal of Research in Counseling and Education, 1(2), 6-12. https://doi.org/10.24036/003za0002

Wong, K. P., Bonn, G., Tam, C. L., \& Wong, C. P. (2018). Preferences for Online and/or Face-to-Face Counseling among University Students in Malaysia. Frontiers in Psychology, 9, 64.

World Health Organization. (2017). Mental Health Status of Adolescents in South-East Asia: Evidence for Action. Retrieved from http://www.who.int/iris/handle/10665/254982 